\title{
Nutritional Significance of Tropical Vegetables in Poultry Feeding: A Review
}

\author{
Muyiwa Adegbenro, ${ }^{1, a, *}$ \\ ${ }^{I}$ Department of Animal Production Health, Faculty of Animal Production and Management Division, The Federal University of Technology, \\ Akure, Nigeria \\ *Corresponding author

\begin{tabular}{|c|c|}
\hline A R T I C L E I N F O & A B S T R A C T \\
\hline $\begin{array}{l}\text { Keywords: } \\
\text { Tropical vegetables } \\
\text { Laying birds } \\
\text { Broiler chickens } \\
\text { Eggs } \\
\text { Meat }\end{array}$ & $\begin{array}{l}\text { In developing nations Nigeria inclusive, most of the cereals grown are for human consumption. } \\
\text { Conventional feedstuffs use in livestock production especially in poultry enterprise has intensified } \\
\text { the competition for available grains. Consequently, the cost of poultry production is jacked up. Since } \\
\text { poultry provides most of the animal protein consumed either in the form of meat or egg, exploring } \\
\text { tropical vegetables as a route of escape to reducing the cost of feeding will be a great gain in the } \\
\text { poultry enterprise. Tropical vegetables especially the African leafy vegetables (ALVs) are } \\
\text { economical and highly nutritive possessing good levels of vitamins, minerals, protein and essential } \\
\text { amino acids. The mineral constituent of some tropical vegetables as well as their nutritive impact on } \\
\text { the performance, meat quality, egg quality in broiler and laying birds as presented in this review } \\
\text { paper. Although, the availability of ALVs all year round, its moisture content level and presence of } \\
\text { anti-nutrients may tend to limit its usage in poultry feed, adopting irrigation techniques and improved } \\
\text { seedlings as well as exploring the processes of enhancing the nutritional value of ALVs to combat } \\
\text { anti-nutrients to tolerable levels by the birds make it possible to be considered as good alternative in } \\
\text { poultry diets. }\end{array}$ \\
\hline
\end{tabular}

madegbenro@futa.edu.ng (iD)https://orcid.org/0000-0001-9275-3998

\section{Introduction}

Agriculture is the most dominant sector of the economies of many developing countries. In Nigeria for example, it contributes about $33.6 \%$ of the Gross Domestic Product (GDP) and about $75 \%$ of export earnings (NSS, 2009). The livestock and poultry sub-sector are estimated to contribute about $6 \%$ of Agricultural GDP. It provides employment and helps to meet the basic meat and animal product requirements for the growing Nigerian population (MoFA, 1990). Commercial poultry production, in particular, provides easily accessible and affordable meat and eggs. About $80 \%$ of the world's population gets most of their basic nutrients like proteins, fats and vitamins from meat and eggs (FAO. 2007). Feeds and feeding constitute a large proportion of the total expenditure in the poultry industry especially when ingredients like grains are used (Teguia and Beynen, 2004).

In many developing countries, most of the cereal grown is for human consumption, and hopefully, surpluses are used for animal feeding. However, the reality is that whatever is available is competed for by humans and livestock for food and feed, respectively. This competition raises the cost of poultry production. A high cost of animal production translates into a high cost of animal protein. Reducing this cost component in animal (particularly poultry) production, therefore, is one way of reducing the cost of poultry products.
Several poultry scientists all over the world are now engaged in research into the use of botanicals and plant-derived products to fight and reduce the heavy economic losses in poultry industry caused by poultry diseases (Abbas, 2013)

Leafy vegetables are the cheapest and most readily available sources of important proteins, vitamins, minerals and essential amino acids (Kwenin et al., 2011). Several vegetable species abound in Nigeria and most West African countries where they are used partly as condiments or spices in human diets or as supplementary feed to livestock such as rabbits, poultry, swine and cattle (Aletor and Adeogun, 1995, Fasuyi, 2005). These vegetables are harvested at all stages of growth and fed either as processed, semi-processed or fresh to man while they are usually offered fresh to livestock. Thus, the focus of this review paper is centred on the nutritional significance of tropical vegetables in poultry feeding.

\section{Nutritional Value of Tropical Vegetables}

African leafy vegetables (ALVs) are the cheapest and most readily available sources of important proteins, vitamins, minerals and essential amino acids (Kwenin et al., 2011). Several vegetable species abound in Nigeria and 
most West African countries where they are used partly as condiments or spices in human diets or as supplementary feed to livestock such as rabbits, poultry, swine and cattle (Fasuyi 2005, Adegbenro 2015). These vegetables are harvested at all stages of growth and fed either as processed, semi-processed or fresh to man while they are usually offered fresh to livestock. Vegetables rank higher in production than all other crops. They are known to provide $80 \%$ of the vitamin $\mathrm{A}$ in the diet (Bosland and Votava, 2000).

A large number of African indigenous leafy vegetables have long been known and reported to have healthprotecting properties and uses (Okeno et al., 2003).Green leafy vegetables are also a great source of minerals such as zinc, iron and potassium as reported by Adegbenro (2015) and the results are presented in Table 1.

Table 1. Macro and micro mineral compositions of the five leaf meals*

\begin{tabular}{l|ccccc}
\hline \multicolumn{1}{c}{ Parameters } & Cassava & Moringa & Fluted pumpkin & Bitter leaf & African Basil \\
\hline \multicolumn{5}{c}{ Macro $(\mathrm{g} / 100 \mathrm{~g})$} \\
Potassium & 1.65 & 1.94 & 1.85 & 1.22 & 1.72 \\
Sodium & 0.25 & 0.25 & 0.25 & 0.20 & 0.24 \\
Calcium & 0.06 & 0.06 & 0.07 & 0.07 & 0.06 \\
Magnesium & 0.28 & 0.30 & 0.24 & 0.22 & 0.27 \\
Phosphorus & 0.27 & 0.18 & 0.22 & 0.21 & 0.17 \\
\hline \multicolumn{7}{c}{ Micro $(\mathrm{mg} / \mathrm{kg})$} \\
Zinc & 16.55 & 17.75 & 17.39 & 13.56 & 15.99 \\
Iron & 32.90 & 29.10 & 32.31 & 34.12 & 29.51 \\
Copper & 4.84 & 4.95 & 3.62 & 4.31 & 4.85 \\
Manganese & 60.00 & 60.14 & 46.99 & 47.58 & 84.71 \\
\hline
\end{tabular}

*Adapted by Adegbenro (2015)

In studies, it is reported that ALVs contain on-nutrient bioactive phytochemicals that have been linked to protection against cardiovascular and other degenerative diseases. In spite of the nutritional contribution of ALVs to local diets, health maintenance and protective properties, there has been very little concerted effort towards exploiting this biodiverse nutritional and health resource to address the complex food, nutrition and health problems of sub-Saharan Africa.

\section{Tropical Vegetables in Poultry Nutrition}

With an increasing demand for animal protein and the development of the poultry industry, there is a need to look for alternative energy sources, protein resources and vitamin-mineral premixes sources for poultry farmers. Different sources of alternative feed available for feeding chickens will raise the standard of living for poultry farmers. Currently, the poultry industry is faced with challenges to produce high-quality animal protein for the populace at low prices. Poultry scientists are now looking for alternatives to expensive and non-available feed resources and one such way is the use of tropical vegetables in poultry diets, therefore, making protein available to people eat cheaper prices. For this review, emphasis will be on laying birds and broiler chickens as the main products from poultry are gotten from these two poultry types.

Numerous experiments had been carried out on the effects of various tropical vegetables on laying birds. Composite leaf meal (Moringa oleifera, Ocimum gratissimum, Manihot esculenta, Telfaria occidentalis and Vernonia amygdalina) as reported by Adegbenro (2015) disclose that its use up to $5 \%$ in layers diet does not only facilitate healthy living but enhance the daily feed intake of the bird as it stimulates appetite, decrease feed conversion ratio and heighten the hen day production compared to the use of conventional premix. Likewise, the use of $5 \%$ Moringaoleifera solely in place of soybean meal in the diet of hens was reported to improve feed conversion ratio and boost total egg weight as well as hen day egg production of laying birds (Wubalem, 2014). Kakengi et al. (2007) observed increased feed intake in laying hens fed diets containing varying levels of Moringaoleifera leaf meal in which inclusion rates were about twofold higher than those of the present study. Ekenyem and Madubuike (2006) reported improved feed intake for broilers fed diets with 5\% Ipomoea asarifolia leaf meal but intake was depressed at $15 \%$. On the other hand, Nworgu and Fasogbon (2007) reported reduced feed intake by Black Nera pullets fed diets containing 2\%, 4\% and 6\% Centrosemapubescens leaf meal. Kakengi et al. (2007), also, reported a positive effect on egg weight when sunflower was substituted with Moringaoleifera at 5\% levels in the diet of laying hens. According to Adegbenro (2015), complete replacement of conventional premix with composite leaf meal, significantly affect percentage egg production of the laying birds. The diet with $5 \%$ composite leaf meal enhanced better hen day production (HDP) than those fed control with conventional premix as a major source of premix. The substitution of conventional premix with composite leaf meal at 5\% levels in the diet showed a positive effect on egg weight which could be associated with higher Sulphur-containing amino acids reported in moringa leaves (Adegbenro, 2015) and this agrees with the earlier report of Kakengi et al. (2007) who reported a positive effect on egg weight when sunflower was substituted with Moringaoleifera at 5\% levels in the diet of laying hens.

Wubalem (2014) reported that the inclusion of 5\% Moringaolifera leaf to layers diet helps to improve eggshell thickness with shell thickness having the range of 0.29-0.38 while shape index was $75-80$ which is in line with the standard given by ISA (2009) who stated that the minimum shell thickness of 0.35 and shape index of 74 are indicators of good egg quality. Higher Yolk weight and heavier shell weight were observed in laying birds fed with 5\% composite leaf meal inclusion as reported by Adegbenro 
(2015). The cholesterol levels of eggs produced from laying birds fed composite leaf meal were reduced (Adegbenro, 2015). The fact that the inclusion of composite leaf meal resulted in a decrease in cholesterol levels affirms its potential as a hypocholesterolemic agent. This is an agreement with the report of Ghasi et al. (1999). The relative reductions in this study compared with that of Ghasi et al. (1999) might be due to differences in the form and quantity of composite leaf meal included in the diets as well as the animal typed used. Laying hens cannot synthesize egg yolk pigments in its body but the egg yolk colour is one of the main indicators of egg quality affecting consumer's preference (Englmaierova et al., 2014). The pigmentation of the egg yolk (xanthophylls) depends on fat-soluble pigments that are present in the feed (Yildirim et al., 2013). According to a survey conducted, poultry farmers adding between $2 \%$ and $4 \%$ of Leucaena leaf meal to their ration have improved egg yolk colour and increased palatability of their laying hens. The egg yolk coloration increased progressively as the level of composite leaf meal increased in the diet of laying birds (Adegbenro, 2015). Also, composite leaf meal affects the yolk and albumen $\mathrm{pH}$. As the level of composite leaf meal increases there is a decrease in the $\mathrm{pH}$ value. But there was an opposite pattern in the whole egg $\mathrm{pH}$ in which the $\mathrm{pH}$ level was insignificant to the control diet. The $\mathrm{pH}$ values observed in the study falls within the range $(7.0-9.0,6.4$, and $7.1-7.9$ for egg white, egg yolk and whole egg, respectively) as earlier reported by FDA (2012). The increase in yolk coloration was also reported by Adegbenro (2015) and this may be as a result of the presence of carotene in the leaves thus supporting the findings that all green plants contain xanthophylls and its source, availability and value will dictate the degree of pigmentation. Possibly, the use of these leaves could be harnessed towards poultry product pigmentation in the tropics where consumers favour deep coloured poultry egg.

From a study conducted by Adegbenro et al. (2017), five (5) tropical vegetables were mixed in ratio $1: 1: 1: 1: 1$ into a composite meal and used to replace broiler commercial premix at 0 . 1. 2. 3. 4 and $5 \%$ in place of $0,20,40,60,80$ and $100 \%$ reduction levels of the commercial premix respectively. The study showed that birds fed on a diet containing 20\%-based composite meal had the highest final weight and best feed conversion ratio with a concomitant highest average price realized per bird and average price gained per bird. Also, there was a trend towards a reduction in the cholesterol level as the inclusion level of composite meal in the diets was increased. Adegbenro et al. (2017) also reported reduction in values for the belly fat as the level of composite leaf meal produced from the five (5) tropical vegetables inclusion increased, thus indicating the potential of the leaf meals to reduction of fat deposition in the muscle and therefore could help in the prevention and reduction of neurodegenerative diseases associated with lipid-rich diets (Upadhyay, 1990; Oforjindu, 2006).The complete replacements of commercial premix with composite leaf meal at $5 \%$ inclusion level led to $\$ 4.00$ reduction. This translates to a colossal savings of $\$ 40,000$ for the diet per tonne by farmers. Also, from the results which show an increase in the revenue in the output of products from birds fed composite leaf meal-based diets which are directly related to an increase in chicken cutting performance. It shows that the inclusion level of composite leaf meal can be done without any effect on the performance of broiler chickens. These findings were in agreement with the findings of Madiya et al. (2004) and Yadav et al. (2014). This observation could encourage broiler farmers especially the backyard poultry farmers in their quest for large scale expansion.

\section{Tropical Vegetables as Extract}

Also, the aqueous extract from Moringaoleifera had immuno-modulatory activity on the immune system of broiler chickens against Newcastle disease (ND) and influence the final body weight of birds supplied with 5000 $\mathrm{mg} / \mathrm{kg}$ leaf extract having the highest value (Faluyi and Agbede, 2018). In another study, the phylogenetic activities of neem, pawpaw and bamboo and their composite leaf meal were explored in broiler chicken performance and health status. It was revealed that broiler chickens performance could be enhanced with the supplementation of bamboo leaf meal and the composite meal of neem, pawpaw and bamboo leaf meals in ratio $1: 1: 1$ when supplemented in broiler chicken diet at $5 \mathrm{~g} / \mathrm{kg}$ with numerical improvement of feed conversion ratio (Oloruntola et al., 2018). Drinking water containing 50ml and $100 \mathrm{ml}$ waterleaf mucilage resulted in better weight gain, daily feed intake, feed conversion ratio, better hen day egg production and egg weight (Mary, 2015). Cabuk et al. (2006) have shown that supplementation with essential oil mixture (Oregano, laurel leaf, sage leaf, myrtle leaf, fennel seeds and citrus peel and $24 \mathrm{mg}$ essential oils per $\mathrm{kg}$ feed) positively influenced not only feed conversation ratio (FCR) of the laying bird but the average egg production in broiler breeders. According to Mary (2015), the inclusion of $200 \mathrm{~g}$ of waterleaf mucilage to the drinking water of laying hen improves shell thickness a great deal as well as shell weight

\section{Limitations of Using Tropical Vegetables in Poultry Nutrition}

Several factors have been generally identified as limiting to the utilization or high incorporation of tropical vegetables in poultry diets. These include low protein content, high fibre, amino imbalance and presence of anti-nutritional factors (McDonald et al., 1988). Likewise, nutritive values of plant proteins depend upon their amino acid composition, presence of toxic materials, biological value, mode of digestion, and the changes arising during processing. Thus, the quality of a feed protein depends not only its nitrogen content, but also on other constituents such as amino acids, their availability digestibility, and physiological utilization of specific amino acids after digestion (Bryden et al., 2000; Bryden, Li., 2003). Some of the limitations affecting the use of vegetable in poultry feeding are listed below:

\section{Nutritive Value}

There are little or no analyses of nutrient availability for feed alternatives, and where there are, the values are not consistent. This may limit their use or cause inadequate inclusion levels. Additionally, the fibre contents may be so high that birds may not be able to optimally utilize them, which lead to growth performance and impaired nutrient retention in turkeys (Sklan et al., 2003). 


\section{Seasonal Availability}

Most crops grow in the wet season of the year with a reduction in numbers of species of plant available for animals at the dry season of the year. Seasons of the year influences the nutritional quality of most tropical vegetables. Some of these alternative feedstuffs may not be available all-year-round, resulting in an inconsistent supply that may force farmers to resort to conventional feedstuffs.

\section{High Moisture Content}

Most tropical vegetables have high moisture content which makes their preservation almost impossible for peasant farmers. The moisture content of biological materials determines its deterioration because of the more the moisture, the more the microbial activities on the tropical vegetables.

\section{Presence of Anti-Nutritional Factors}

The utilization of tropical vegetable had been limited as a result of the presence of phytate, oxalate, tannin, cyanogenic glucosides, etc. These anti-nutritional factors negate growth and other physiological activities at higher inclusion levels (Oresegun and Alegbeleye, 2001).

\section{Processes to Improve the Nutritional Value of Tropical Vegetable in Poultry Feeds}

The sustenance of ALVs in poultry diets can be achieved if only the aspect of the anti-nutritional factor in the leaf meals, as well as plant breed and breeding, is worked on. Due to climate variability, some of the ALVs may not be available all year round. As a result, there is a need to select for tropical vegetables seedlings or breeds which will yield well under tropical conditions and provide resistance to newly emerging pests and diseases. According to Mosenthin and Sauer (2011), nutrients are better utilized in ground form. Subsequently, voluntary feed intake is improved as digestibility rate is enhanced which have an overall effect on the weight gained by the bird.

\section{Conclusion}

The enormous benefits of ALVs in poultry production cannot be overlooked. Aside from the fact that it is economical, reducing the cost of production, it is highly nutritive if incorporated in bird diets in the right proportion without no adverse effect on the performance and productivity of birds when fed to the birds as meal or extract under intensive rearing system.

\section{References}

Abbas TE. 2013. The use of Moringaoleifera in poultry diets. Turk. J. Vet. Anim. Sci. 37: 492-496.

Adegbenro M. 2015. Characterization of some tropical leaves and their replacement values for commercial vitamin or mineral premix in poultry and swine diets. A PhD thesis submitted to the Department of Animal Production and Health, Federal University of Technology, Akure.
Adegbenro M, Ayeni AO, Agbede JO, Onibi GE, Aletor VA. 2017. Performance characteristics of broiler chickens fed composite leaf meal as alternative premix. Animal Research International 14(3): $2883-2891$.

Aletor VA, Adeogun OA. 1995. Nutrient and anti-nutrien constituents of some tropical vegetables. Food Chemistry 53(4):375-379.

Bosland PW, Votava EJ. 2000. Peppers: vegetable and spice capsicums. CABI publishing, UK

Bryden WL, Hew LI, Ravindran V. 2000. Digestible amino acid values: variation and application. Proceedings Australian Poultry Science Symposium No.12:51-58.

Bryden WL, LI X. 2003.Prediction of amino acids digestibility of complete broiler diets. Proceedings Australian Poultry Science Symposium, No.12:15:67.

Çabuk M, Bozkurt M, Alicukek A, Çatli AU, Baser KHC, 2006. Effect of a dietary essential oil mixture on performance of laying hens in the summer season. South Afr. J Anim. Sci. 36: 215-221.

Ekenyem BU, Madubuike FN. 2006. An assessment of Ipomoea ascarifolia leaf meal as feed ingredient in broiler chick production. Pakistan Journal of Nutrition 5(1): $46-50$.

Englmaierova M, Bubancova I, Skrivan M. 2014. Carotenoids and egg quality. Acta Fytotechnica et Zootechnica 17: 55-57.

Faluyi OB, Agbede JO. 2018. Immuno-Modulatory Activity of Aqueous Leaf Extract of Moringaoleifera in Brioler Chickens. International Journal of Environment, Agriculture and Biotechnology 3(1): 49-54.

FAO 2007. Animal Feed Resources Information System. Food and Agriculture Organization of the United Nations, Rome.

Fasuyi AO, 2005. Nutrient composition and processing effects on cassava leaf (Manihotesculenta, Crantz) antinutrients. Pak J. Nutr. 4: 37-42.

FDA 2012. Bad Bug Book: Handbook of Food borne Pathogenic Microorganisms and Natural Toxins. Center for Food Safety and Applied Nutrition (CFSAN), Food and Drug Administration (FDA), USA. https://www.fda.gov/downloads/Food/ FoodborneIllness Contaminants/UC M297627.pdf Accessed March 15, 2018.

Ghasi S, Nwobodo E, Ofili JO. 1999. Hypocholesterolemic effects of crude extract of leaf of moringaoleifera Lam in high-fat diet fed Wister rats. Journal of Ethnopharmacology 69: 21-25

ISA 2009. From egg to Chicken. Hatchery manual. Pp 37-50.

Kakengi A, Kaijage JT, Sarwatt SV, Mutayoba SK, Shem MN, Fujihara T. 2007. Effect of Moringaoleifera leaf meal as a substitute for sunflower seed meal on performance of laying hens in Tanzania. Livestock Research for Rural Development 19 (8) 2007 (http://www.lrrd.org/lrrd19/8/kake19120.htm, reaching time: 16.04 .2020$)$

Kwenin WK J, Wolli M, Dzomeku BM. 2011. Assessing the nutritional value of some African Indiginous green leafy vegetables in Ghana. Journal of Animal and Plant Sciences 10(2): $1300-1305$.

Madiya AT, Mccrindle CME, Veary CM. 2004. The use of dried bakery products in a free-choice feeding method for smallscale broiler production. Journal of the South African Veterinary Association 74(4): 111 - 116.

Mary S. 2015. Evaluation of quality and cholesterol level of eggs of laying hens placed on drinking water fortified with waterleaf (Talinumtriangulae) mucilage. American scientific Research Journal for Engineering, Technology, and Sciences (ASRJETS) 13(1): 81-87.

McDonald P, Edwards RA, Greenhalgh JFD, Morgan CA. 1995.Animal Nutrition. Edinburgh UK: Addison Wesley Longman Ltd.

Ministry of Food and Agriculture (MoFA) 1990. Nigeria Medium Term Agricultural Development Program (MTADP). An agenda for sustained Agricultural growth and development (1991-2000). Nigeria. 
Mosenthin R, Sauer N. 2011. Nutritional impact of feed particle size in diets for pigs. Proceedings of the Society of Nutrition Physiology 20: 150-156.

Nigeria Statistical Service (NSS), 2009. Nigeria Living Standards Survey. Report of the fifth round (NLSS 5)

North MO, Bell DD. 1990. Breeder Management. In: "Commercial Chicken Production Manual". 4th Ed., Van Nostrand Reinhold. NewYork, USA.

Nworgu FC, Fasogbon FO. 2007. Centrosema (Centrosemapubescens) leaf meal as protein supplement for pullet chicks and growing pullets. International Journal of Poultry Science 6(4): 255 - 260.

Oforjindu O. 2006. The toxicity of graded levels of Neem (Azadirachtaindica) leaf meal. B. Agric Tech. Project Report, Federal University of Technology, Owerri.

Okeno JA, Chebet DK, Mathenge PW. 2003. Status of indigenous vegetables in Kenya. ACTA Hort. 621:95-100.

Oloruntola OD, Agbede JO, Ayoade SO, Ayedun ES, Daramola OT, Oloruntola DA. 2018. Gliricidia leaf meal and multienzyme in rabbits' diets: Effect on performance, blood indices, serum metabolites and antioxidants status. Journal of Animal Science and Technology 60 (24): 1-8.

Oresegun A, Alegbeleye WO. 2001. Serum and tissue thiocynate concentration in tilapia (Oreochromisniloticus) fed cassava peels-based diets supplemented with D.L-methionine. In: AA. Eyo (Ed.), Fish Nutrition and Fish Feed. Published by FISON, Nigeria: $107-115$.
Sklan DA, Smirnov A, Plavnik I. 2003. The effect of dietary fibre on the small intestines and apparent digestion in the turkey. British Poultry Science (44): 735 - 740.

Teguia A, Beynen AC.2004.Nutritional aspects of broiler production in small-holder Farms in Cameroon. Livestock Res. Rural Develop. 16: Art. \#17.

Upadhyay C 1990. The medicinal properties of Neem (Azadirachtaindica) tree. In:Ogbuewu, IP., Okoli IC., Iloeje MU. (eds.) Serum Biochemical Evaluation and organ weight characteristics of Buck Rabbits fed graded levels of neem (Azadirachtaindica). Animal Pharmacology, Second edition, Longman, England.

Wubalem AA. 2014. Effects of different dietary levels of Moringaoleifera leaf meal on egg production, quality, shelf life, fertlity and hatchablity of dual purpose Koekoek hens. Msc. Thesis.

Yadav DS, Shrivastava M, Singh JP, Mishra AK. 2014. Effect of replacement of maize with bakery waste in broiler ration. International Journal of Agricultural Sciences and Veterinary Medicine 2(1): $28-33$.

Yildirim A, Sekeroglu A, Eleroglu H, Sen MI, Duman M. 2013. Effects of Korean ginseng (Panax ginseng CA. Meyer) root extract on egg production performance and egg quality of laying hens. South African Journal of Animal Science 43:194207. 